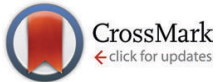

Cite this: New J. Chem., 2016, 40, 7181

Received (in Victoria, Australia) 6th April 2016

Accepted 20th June 2016

DOI: $10.1039 / c 6 n j 01068 \mathrm{~g}$

www.rsc.org/njc

\section{Hexahalometallate salts of trivalent scandium, yttrium and lanthanum: cation-anion association in the solid state and in solution $\uparrow$}

\author{
Martin J. D. Champion, William Levason, David Pugh and Gillian Reid*
}

\begin{abstract}
The hexahalide salts, $\left[\mathrm{N}^{n} \mathrm{Bu}_{4}\right]_{3}\left[\mathrm{LaCl}_{6}\right],[\mathrm{BMPYRR}]_{3}\left[\mathrm{LaCl}_{6}\right]$ (BMPYRR = 1-butyl-1-methylpyrrolidinium), $\left[\mathrm{EMIM}_{3}\left[\mathrm{MX}_{6}\right]\right.$ (EMIM = 1-ethyl-3-methylimidazolium; $M=\mathrm{La}, \mathrm{X}=\mathrm{Cl}, \mathrm{Br}, \mathrm{I} ; \mathrm{M}=\mathrm{SC}, \mathrm{Y}, \mathrm{Ce}, \mathrm{X}=\mathrm{Cl}$ ) and $\left[\mathrm{EDMIM}_{3}\left[\mathrm{MX}_{6}\right]\right.$ (EDMIM = 1-ethyl-2,3-dimethylimidazolium; $M=Y, X=C l ; M=L a, X=C l, I$ ) have been prepared and $X$-ray crystal structures determined for several of them, with a view to probing the effect of varying the trivalent metal ion, the halide and the counter-cation on the structures adopted in the solid state. The crystal structures of the EMIM and EDMIM salts show extensive $\mathrm{H}$-bonding between the halide ligands and organic cations; based upon the $\mathrm{H}$-bonding distances, this appears to be strongest for the $[\mathrm{EMIM}]_{3}\left[\mathrm{MCl}_{6}\right]$ salts, becoming progressively weaker for heavier metal ion or halide. In terms of the cations, changing from EMIM to EDMIM also reduces the strength of the $\mathrm{H}$-bonding. The strength of the cation-anion pairing in solution has also been probed in solution via NMR spectroscopy where possible $\left({ }^{45} \mathrm{SC},{ }^{89} \mathrm{Y}\right.$ and $\left.{ }^{189} \mathrm{La}\right)$ and, for the EMIM salts, via the shift of $\delta(\mathrm{H} 2)$ relative to [EMIM]Cl at a standard concentration. The trends observed in solution mirror those determined in the solid state.
\end{abstract}

\section{Introduction}

In the course of our work on electrodeposition of metals and semiconductors from unusual low polarity solvents, such as $\mathrm{CH}_{2} \mathrm{Cl}_{2}{ }^{1}$ and supercritical $\mathrm{CH}_{2} \mathrm{~F}_{2}$, ${ }^{2}$ we have established that halometallates can often offer both the solubility and extent of dissociation into discrete cations and anions to be highly effective as reagents for delivering the elements of choice. Taking germanium as an example, we have shown that the cation, halide and anion charge all play an important role in determining the extent of cation-halogermanate anion association both in the solids and in solution. ${ }^{3}$ While we have often used quaternary ammonium salts for this purpose, recent work on the electrodeposition of elemental germanium from supercritical $\mathrm{CH}_{2} \mathrm{~F}_{2}$ has established that using the 1-ethyl-3-methylimidazolium (EMIM) cation leads to improved quality of the electrodeposited germanium, ${ }^{4}$ and hence this and other substituted imidazolium cation salts, which are also used extensively for electrodeposition from ionic liquids, ${ }^{5}$ have become of greater importance in this area of work.

In order to gain a better understanding of the cation-anion association in halometallate salts, we describe here a study of

School of Chemistry, University of Southampton, Southampton SO17 1BJ, UK. E-mail: G.Reid@soton.ac.uk

$\dagger$ CCDC 1472564 ([EMIM $\left.]_{3}\left[\mathrm{ScCl}_{6}\right]\right), 1472565$ ([EMIM $\left.]_{3}\left[\mathrm{YCl}_{6}\right]\right), 1472566$ ([EMIM] $\left.]_{3}\left[\mathrm{CeCl}_{6}\right]\right)$, $1472567\left([\mathrm{EMIM}]_{3}\left[\mathrm{LaBr}_{6}\right]\right), 1472568$ ([EMIM $\left.]_{3}\left[\mathrm{LaI}_{6}\right]\right), 1472569$ ([EDMIM $\left.]_{3}\left[\mathrm{YCl}_{6}\right]\right), 1472570$ $\left([\mathrm{EDMIM}]_{3}\left[\mathrm{LaCl}_{6}\right]\right)$ and $1472571\left([\mathrm{EDMIM}]_{3}\left[\mathrm{LaI}_{6}\right]\right)$. For crystallographic data in CIF or other electronic format see DOI: $10.1039 / \mathrm{c} 6 \mathrm{nj} 01068 \mathrm{~g}$ the $\left[\mathrm{MX}_{6}\right]^{3-}$ trianions incorporating a range of trivalent metal ions from group 3 and the lanthanides, in the anticipation that the trianionic charge would give rise to significant cation-anion association both in the solid state and in low polarity solvents. We report the synthesis of a series of halometallate anion salts of scandium, yttrium and several lanthanides. All complexes have been characterised by NMR spectroscopy $\left({ }^{1} \mathrm{H},{ }^{45} \mathrm{Sc},{ }^{89} \mathrm{Y}\right.$ and ${ }^{139} \mathrm{La}$ as appropriate), IR spectroscopy, elemental analysis and, in several cases, single-crystal X-ray diffraction. To gain further insight into the cation-anion pairing in these species, we have explored the effects that systematic changes in the countercation, metal ion and halide co-ligands have on the solid-state structures adopted and the spectroscopic behaviour of these halometallate salts in $\mathrm{MeCN}$ (and where possible, $\mathrm{CH}_{2} \mathrm{Cl}_{2}$ ) solution.

A small number of earlier studies report structural data on halometallate salts of the $\mathrm{Ln}(\mathrm{III})$ ions. The examples most pertinent to the present study are $[\mathrm{EMIM}]_{3}\left[\mathrm{LnCl}_{6}\right](\mathrm{Ln}=\mathrm{La}, \mathrm{Pr}, \mathrm{Nd}$, $\mathrm{Sm}, \mathrm{Eu})$ grown from hydrated $\mathrm{LnCl}_{3}$ in [EMIM] Cl at $110{ }^{\circ} \mathrm{C},{ }^{6,7}$ $[\mathrm{MPPYRR}]_{3}\left[\mathrm{NdI}_{6}\right]\left(\mathrm{MPPYRR}=1\right.$-methyl-1-propylpyrrolidinium) ${ }^{8}$ and $\left[\mathrm{SEt}_{3}\right]_{3}\left[\mathrm{LnI}_{6}\right](\mathrm{Ln}=\mathrm{Nd}, \mathrm{Sm})$, obtained from reaction of $\mathrm{LnI}_{2}$ with the ionic liquid $\left[\mathrm{SEt}_{3}\right]\left[\mathrm{NTf}_{2}\right]\left(\mathrm{NTf}_{2}=\right.$ bis-(trifluoromethanesulfonyl)imide). ${ }^{9}$ A very recent study has described the structures of a series of $[\mathrm{BMIM}]_{3}\left[\mathrm{CeX}_{6}\right]$ salts (BMIM = 1-butyl-3-methylimidazolium), also obtained directly from $\mathrm{CeX}_{3}$ in the [BMIM]X ionic liquids, which are reported to exhibit intense $\mathrm{Ce}^{3+}$ based $5 \mathrm{~d}-4 \mathrm{f}-$ centred emission. ${ }^{10}$ 


\section{Results and discussion}

\section{Preparations}

The hexahalide salts, $\left[\mathrm{N}^{n} \mathrm{Bu}_{4}\right]_{3}\left[\mathrm{LaCl}_{6}\right],[\mathrm{BMPYRR}]_{3}\left[\mathrm{LaCl}_{6}\right](\mathrm{BMPYRR}=$ 1-butyl-1-methylpyrrolidinium, [EMIM $]_{3}\left[\mathrm{MX}_{6}\right](\mathrm{M}=\mathrm{La}, \mathrm{X}=\mathrm{Cl}, \mathrm{Br}, \mathrm{I}$; $\mathrm{M}=\mathrm{Sc}, \mathrm{Y}, \mathrm{Ce}, \mathrm{X}=\mathrm{Cl}$ ) and $[\mathrm{EDMIM}]_{3}\left[\mathrm{MX}_{6}\right]$ (EDMIM = 1-ethyl-2,3dimethylimidazolium; $\mathrm{M}=\mathrm{Y}, \mathrm{X}=\mathrm{Cl} ; \mathrm{M}=\mathrm{La}, \mathrm{X}=\mathrm{Cl}$, I), were selected for study on the basis that they would allow us to probe the effects that the cation (extent of H-bonding or not), the metal ion size and the halide type have upon the solid state and solution properties. The salts were readily prepared as powdered solids in good yield by treatment of anhydrous $\mathrm{MX}_{3}$ with three (or slightly greater) molar equivalents of the appropriate halide salt of the organic cation, $\left[\mathrm{N}^{n} \mathrm{Bu}_{4}\right]^{+},[\mathrm{BMPYRR}]^{+},[\mathrm{EMIM}]^{+}$or $\left.[\mathrm{EDMIM}]^{+}\right)$in $\mathrm{MeCN}$, acetone or $\mathrm{CH}_{2} \mathrm{Cl}_{2}$ solution, and their formulations were confirmed by microanalyses. The isolated salts are moderately soluble in MeCN and, in some cases, in $\mathrm{CH}_{2} \mathrm{Cl}_{2}$ solution. Crystals of several examples with EMIM and EDMIM cations were obtained by vapour diffusion of $\mathrm{Et}_{2} \mathrm{O}$ into a concentrated MeCN solution of the relevant salt.

\section{Varying the halide}

In order to assess the effect of varying the halide on the nature of the hydrogen bonding interactions, the $[\mathrm{EMIM}]_{3}\left[\mathrm{LaX}_{6}\right]$ system (X $=\mathrm{Cl}, \mathrm{Br}, \mathrm{I})$ was chosen. $[\mathrm{EMIM}]_{3}\left[\mathrm{LaCl}_{6}\right]$ had previously been synthesised and crystallographically characterised. ${ }^{6,7}$ Crystals of the bromide (Fig. 1) and iodide (Fig. 2) analogues were obtained by slow diffusion of $\mathrm{Et}_{2} \mathrm{O}$ into an MeCN solution. Surprisingly these are rare examples of discrete $\left[\mathrm{LaX}_{6}\right]^{3-}$ anions with organic cations: $[2,4,6 \text {-trimethylpyridinium }]_{4}\left[\mathrm{LaCl}_{6}\right] \mathrm{Cl}^{11}$ and $[\mathrm{BMPYRR}]_{4}\left[\mathrm{LaI}_{6}\right]\left[\mathrm{NTf}_{2}\right]^{12}$ are the only other structurally authenticated complexes.

$[\mathrm{EMIM}]_{3}\left[\mathrm{LaCl}_{6}\right]$ and $[\mathrm{EMIM}]_{3}\left[\mathrm{LaBr}_{6}\right]$ are isomorphous and isostructural, whereas $[\mathrm{EMIM}]_{3}\left[\mathrm{LaI}_{6}\right]$ crystallises with a different unit cell, presumably reflecting the increased steric requirements of $\mathrm{I}^{-}$over $\mathrm{Br}^{-}$and $\mathrm{Cl}^{-}$. Nonetheless, in each case the $\left[\mathrm{LaX}_{6}\right]^{3-}$ anion is octahedrally coordinated with six halides comprising the primary coordination sphere. Two crystallographically independent $\left[\operatorname{LaX}_{6}\right]^{3-}$ anions were observed in the solid state with different arrangements of hydrogen bonding cations, including bifurcated hydrogen bonding, accounting for the difference. Most of the hydrogen bonding occurs through the acidic NCN proton of the imidazolium ring but interactions through the NCCN backbone protons (which are less acidic) were also observed, resulting in an extended structure in the solid state (Fig. 2(b)).

Here it should be noted that in our experience, the criteria used for assigning the strength of hydrogen bonds ${ }^{13}$ are not always applicable where metal complexes with heavy halogens are acting as acceptors. Other important factors such as crystal packing effects and $\pi$-bonding interactions can have a significant effect on the donor-acceptor distances and donor-hydrogenacceptor (DHA) angles which are used to classify 'strong', 'moderate' or 'weak' hydrogen bonds. Typically, these DHA interactions are quantified via the crystallographically determined $\mathrm{D} \cdots \mathrm{A}(\mathrm{C} \cdots \mathrm{X})$ distances. The radii of $\mathrm{Br}^{-}$and especially $\mathrm{I}^{-}$also have an effect on the $\mathrm{C} \cdot \mathrm{X}$ bond lengths. Nonetheless, for a given halide, the shortest $\mathrm{C} \cdot \mathrm{X}$ distances for the $[\mathrm{EMIM}]_{3}$ $\left[\mathrm{LaX}_{6}\right]$ series of complexes (Table 1 ) occur where the NCN proton (H2) acts as the donor, consistent with it being the most acidic proton on the imidazolium ring. The $\mathrm{C} \cdots \mathrm{X}$ distances where the backbone NCCN protons $(\mathrm{H} 4 / \mathrm{H} 5)$ act as donors are typically 0.1-0.2 Å longer, implying weaker hydrogen bonding. In all cases the DHA angles are also generally greater than $130^{\circ}$, hence we assign these as 'moderate' hydrogen bonds.

\section{Varying the metal}

Another variable to assess in this series of complexes is the nature of the metal ion. By choosing a range of trivalent metals for $[\mathrm{EMIM}]_{3}\left[\mathrm{MCl}_{6}\right](\mathrm{M}=\mathrm{Sc}, \mathrm{Y}, \mathrm{La}, \mathrm{Ce})$ it is possible to vary the ionic radius, and hence the charge: radius ratio, and observe the effect on the hydrogen bonding. Addition of [EMIM]Cl to $\mathrm{MCl}_{3}$ led to the formation of crystalline samples of $[\mathrm{EMIM}]_{3}$ $\left[\mathrm{ScCl}_{6}\right]$ (Fig. 3), [EMIM $]_{3}\left[\mathrm{YCl}_{6}\right]$ (Fig. 4) and $[\mathrm{EMIM}]_{3}\left[\mathrm{CeCl}_{6}\right]$ (Fig. 5).
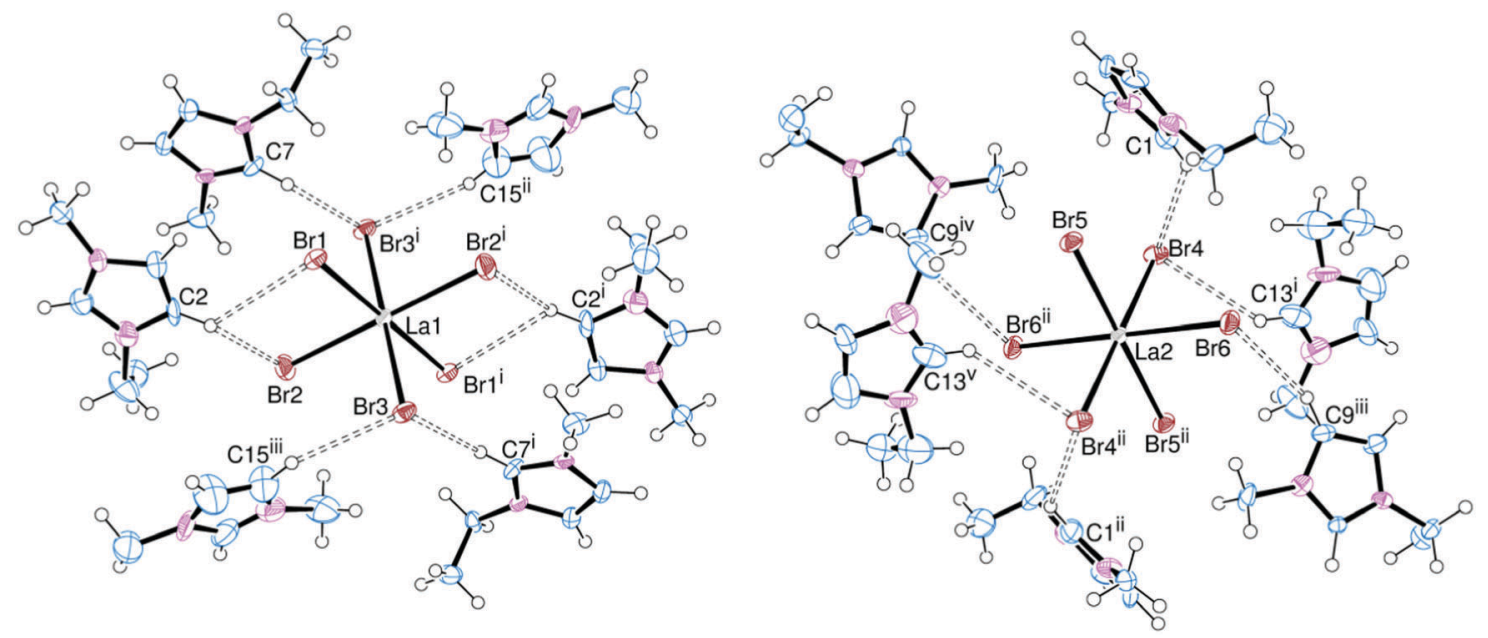

Fig. 1 ORTEP representation of $[E M I M]_{3}\left[\mathrm{LaBr}_{6}\right]$ showing the hydrogen bonding (dotted lines) surrounding the La1-centred cation (left) and the La2centred cation (right). Displacement ellipsoids are drawn at the 50\% probability level. Selected bond lengths (Å): La1-Br1 2.9371(13), La1-Br2 2.9296(16), La1-Br3 2.9534(13), La2-Br4 2.9477(15), La2-Br5 2.9484(14), La2-Br6 2.9524(13). Symmetry codes: (i) $2-x, 1-y, 1-z$; (ii) $1-x, 1-y$, $-z$. 

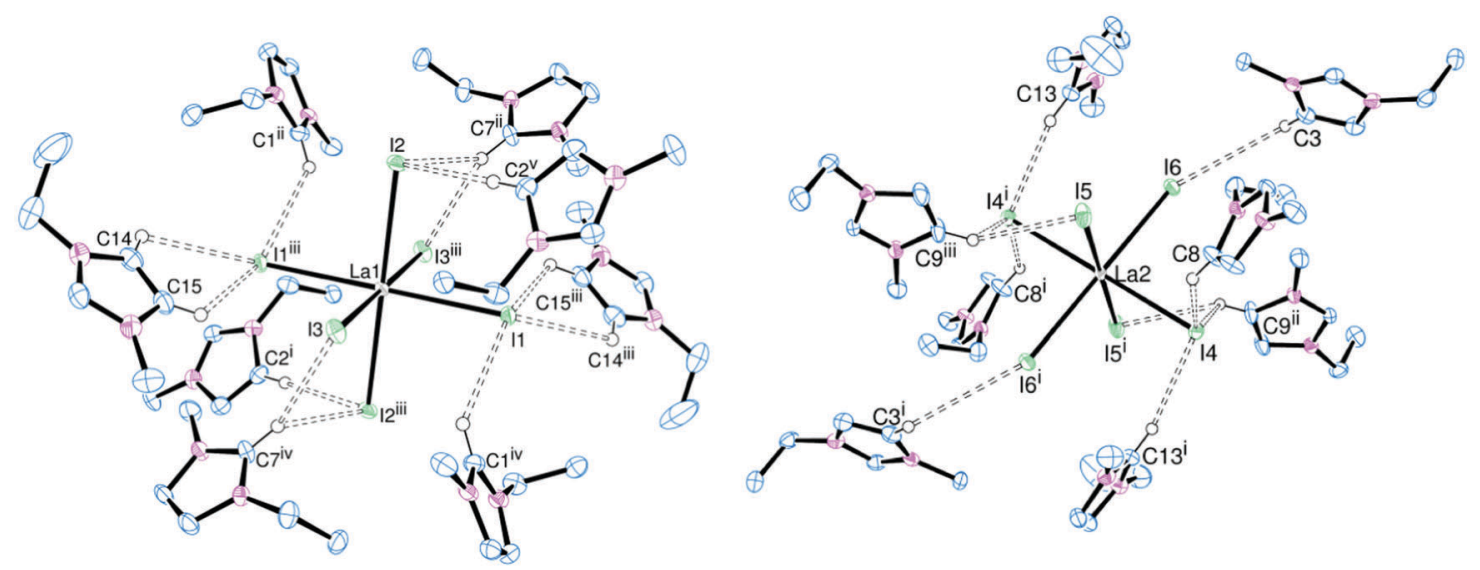

(a)

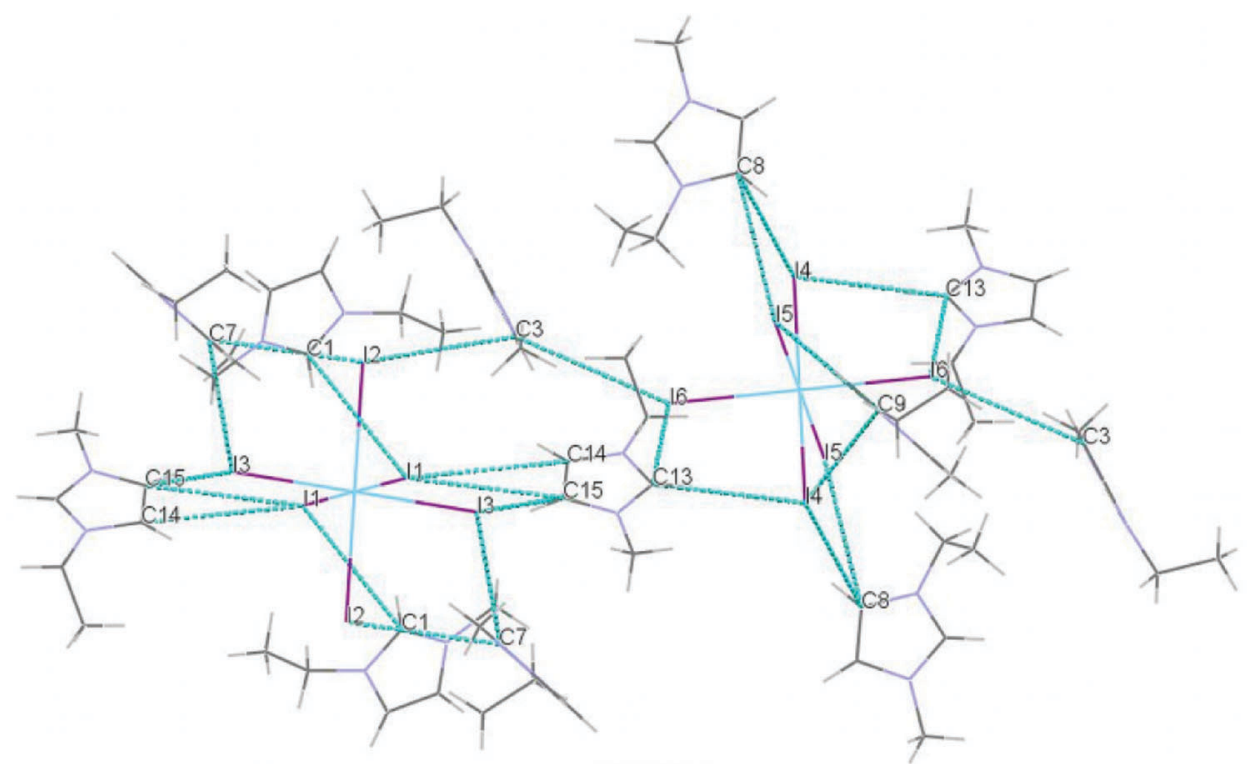

(b)

Fig. 2 (a) ORTEP representation of [EMIM] $]_{3}\left[\mathrm{Lal}_{6}\right]$ showing the hydrogen bonding (dotted lines) surrounding the La1-centred cation (left) and the La2centred cation (right). Displacement ellipsoids are drawn at the 50\% probability level and $\mathrm{H}$ atoms not involved in hydrogen bonding are omitted for clarity. Selected bond lengths (Å): La1-I1 3.1557(5), La1-I2 3.1448(4), La1-13 3.1930(8), La2-14 3.1988(5), La2-I5 3.1663(5), La2-16 3.1733(10). Symmetry codes: (i) $1-x, 3-y, 1-z$; (ii) $-x, 2-y, 1-z$; (iii) $x, 2.5-y, 1.5-z$; (iv) $1-x, 0.5-y, 1-z$; (v) $1-x, 0.5-y, 1.5-z$. (b) Representation of [EMIM] ${ }_{3}[$ Lal 6 ] showing the extended structure generated by the hydrogen bonding (dotted lines).

The Sc and Y complexes are isostructural and isomorphous, with a slight increase in cell parameters owing to the increase in metal ionic radius ( $\mathrm{Sc}=0.745 \AA, \mathrm{Y}=0.90 \AA$ for 6-coordinate complexes). ${ }^{14}$ The known lanthanide examples are structurally different, but within the series (including $\mathrm{La}, \mathrm{Eu}, \mathrm{Gd}, \mathrm{Nd}, \mathrm{Pr}$ and Sm analogues) they are all isomorphous and isostructural ${ }^{7}$ and the cell parameters for $[\mathrm{EMIM}]_{3}\left[\mathrm{CeCl}_{6}\right]$ fit well with this trend.

In the solid state all the metal centres are six-coordinate regular octahedra. There is only one metal environment in the asymmetric unit of $[\mathrm{EMIM}]_{3}\left[\mathrm{ScCl}_{6}\right]$ and $[\mathrm{EMIM}]_{3}\left[\mathrm{YCl}_{6}\right]$ and the hydrogen bonding interactions are very similar (Table 2). Despite the decreased charge:radius ratio for $\mathrm{Y}$ over Sc, the hydrogen bonds through $\mathrm{H} 4 / 5$ are identical within experimental error.
However, there is a small increase in the hydrogen bond lengths involving $\mathrm{H} 2$ for $[\mathrm{EMIM}]_{3}\left[\mathrm{YCl}_{6}\right]$ compared to $[\mathrm{EMIM}]_{3}\left[\mathrm{ScCl}_{6}\right]$. These are notably shorter than the equivalent bonds in $[\mathrm{EMIM}]_{3}$ $\left[\mathrm{LaCl}_{6}\right]$, continuing the same trend. Trifurcated hydrogen bonding is present in $[\mathrm{EMIM}]_{3}\left[\mathrm{CeCl}_{6}\right]$ through $\mathrm{C} 13$ (Fig. 5).

\section{Varying the cation}

Altering the nature of the cation can have a marked effect on the structural properties of the complexes. In order to probe this effect the $[\mathrm{CATION}]_{3}\left[\mathrm{LaCl}_{6}\right]$ system was initially chosen $(\mathrm{CATION}=\mathrm{EMIM}$, EDMIM, $\mathrm{N}^{n} \mathrm{Bu}_{4}$ and BMPYRR). Complexes were prepared by adding a slight excess of [CATION]Cl to $\mathrm{LaCl}_{3}$ in $\mathrm{MeCN}$, resulting in a series of compounds where the hydrogen bonding interactions should be 
Table 1 Hydrogen bond data for the $\left[\mathrm{EMIM}_{3}\left[\mathrm{LaX}_{6}\right]\right.$ series of compounds

\begin{tabular}{|c|c|c|c|c|c|c|}
\hline & \multicolumn{2}{|c|}{$[\mathrm{EMIM}]_{3}\left[\mathrm{LaCl}_{6}\right]^{a}$} & \multicolumn{2}{|c|}{$\underline{\mathrm{EMIM}}]_{3}\left[\mathrm{LaBr}_{6}\right]$} & \multicolumn{2}{|c|}{$\underline{\mathrm{EMIM}}]_{3}\left[\mathrm{LaI}_{6}\right]$} \\
\hline & $\begin{array}{l}\text { Length } \\
(\AA)\end{array}$ & $\begin{array}{l}\text { Angle } \\
\left({ }^{\circ}\right)\end{array}$ & $\begin{array}{l}\text { Length } \\
(\AA)\end{array}$ & $\begin{array}{l}\text { Angle } \\
\left({ }^{\circ}\right)\end{array}$ & $\begin{array}{l}\text { Length } \\
(\AA)\end{array}$ & $\begin{array}{l}\text { Angle } \\
\left({ }^{\circ}\right)\end{array}$ \\
\hline \multirow[t]{4}{*}{$\mathrm{C} \cdots \mathrm{X}(\mathrm{H} 2)$} & $3.557(8)$ & 152.2 & $3.579(12)$ & 134.2 & $3.942(5)$ & 139.8 \\
\hline & $3.479(6)$ & 131.6 & $3.659(10)$ & 153.8 & $3.758(5)$ & 134.0 \\
\hline & $3.393(4)$ & 120.2 & $3.765(17)$ & 134.7 & $3.864(5)$ & 134.9 \\
\hline & $3.612(4)$ & 150.2 & & & $3.825(5)$ & 160.4 \\
\hline \multirow[t]{7}{*}{$\mathrm{C} \cdots \mathrm{X}(\mathrm{H} 4 / 5)$} & $3.635(5)$ & 150.3 & $3.723(12)$ & 121.6 & $3.974(5)$ & 136.7 \\
\hline & $3.614(6)$ & 148.4 & $3.683(11)$ & 139.8 & $3.972(5)$ & 113.5 \\
\hline & $3.692(5)$ & 146.7 & $3.744(12)$ & 118.3 & $3.796(5)$ & 143.2 \\
\hline & $3.632(5)$ & 145.9 & $3.755(11)$ & 146.8 & $3.894(5)$ & 119.0 \\
\hline & $3.564(6)$ & 137.5 & $3.708(12)$ & 145.1 & $3.830(5)$ & 124.0 \\
\hline & & & $3.693(12)$ & 153.7 & $4.210(5)$ & 172.5 \\
\hline & & & $3.708(16)$ & 143.9 & & \\
\hline
\end{tabular}

${ }^{a}$ Data from ref. 7.

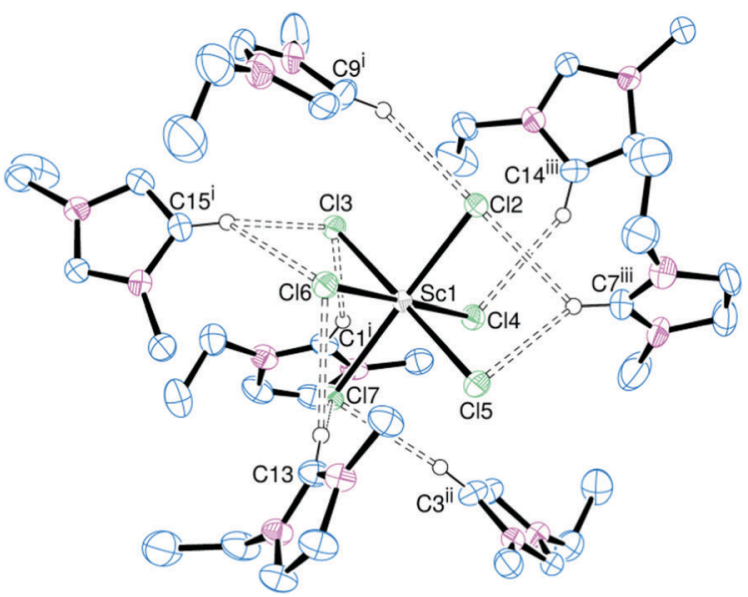

Fig. 3 ORTEP representation of $[E M I M]_{3}\left[\mathrm{ScCl}_{6}\right]$ showing the hydrogen bonding (dotted lines). Displacement ellipsoids are drawn at the 50\% probability level and hydrogen atoms not involved in hydrogen bonding are omitted for clarity. Selected bond lengths (Å): Sc-Cl2 2.479(1), $\mathrm{Sc}-\mathrm{Cl} 3$ 2.513(1), Sc-Cl4 2.5066(7), Sc-Cl5 2.520(1), Sc-Cl6 2.4735(8), Sc-Cl7 2.522(1). Symmetry codes: (i) $1-x,-y, z-0.5$; (ii) $x-0.5,0.5-y, z$; (iii) $x, y-1, z$.

moderate (EMIM), weak (EDMIM) and non-existent $\left(\mathrm{N}^{n} \mathrm{Bu}_{4}\right.$, BMPYRR). The difference between the $[\mathrm{EDMIM}]^{+}$cation and the $[\mathrm{EMIM}]^{+}$cation is the presence of a methyl group at the $\mathrm{C} 2$ position, thus the most acidic protons are now on the backbone of the imidazolium ring. This was expected to significantly influence the hydrogen bonding. The structure of $[\mathrm{EDMIM}]_{3}\left[\mathrm{LaCl}_{6}\right]$ is shown in Fig. 6.

Structural characterisation of $[\mathrm{EDMIM}]_{3}\left[\mathrm{LaCl}_{6}\right]$ revealed that the $\left[\mathrm{LaCl}_{6}\right]^{3-}$ trianion was stabilised by hydrogen bonding through five associated $[\mathrm{EDMIM}]^{+}$cations. The $\mathrm{C} \cdot \mathrm{Cl}$ distances were slightly shorter than the corresponding C...Cl distances for $[\mathrm{EMIM}]_{3}\left[\mathrm{LaCl}_{6}\right]$, suggesting that hydrogen bonding through the backbone protons may be slightly stronger when no $\mathrm{H} 2$ proton is present. However, ${ }^{1} \mathrm{H}$ NMR data (below) show that the chemical shifts for $\mathrm{H} 4 / 5$ are consistent with complete dissociation of the molecule in $\mathrm{CD}_{3} \mathrm{CN}$ solution. The $\mathrm{La}-\mathrm{Cl}$ bond lengths are comparable to those observed for $[\mathrm{EMIM}]_{3}\left[\mathrm{LaCl}_{6}\right]$.

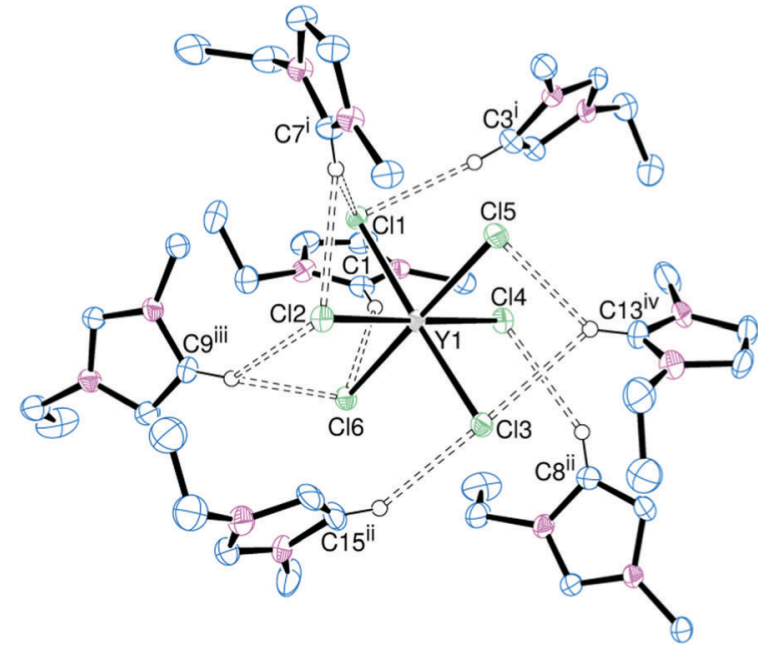

Fig. 4 ORTEP representation of $[E M I M]_{3}\left[\mathrm{YCl}_{6}\right]$ showing the hydrogen bonding (dotted lines). Displacement ellipsoids are drawn at the 50\% probability level and hydrogen atoms not involved in hydrogen bonding are omitted for clarity. Selected bond lengths (Å): $Y-C l 1 ~ 2.6541(12)$, $\mathrm{Y}-\mathrm{Cl} 2$ 2.614(1), $\mathrm{Y}-\mathrm{Cl}$ 2.6185(12), $\mathrm{Y}-\mathrm{Cl} 4$ 2.640(1), $\mathrm{Y}-\mathrm{Cl}$ 2.6515(14), Y-Cl6 2.6524(14). Symmetry codes: (i) $1-x, 1-y, z-0.5$; (ii) $0.5-x$, $y-0.5, z-0.5$; (iii) $x, y-1, z$; (iv) $x, y, z-1$.

A comparison between the $[\mathrm{EMIM}]^{+}$and $[\mathrm{EDMIM}]^{+}$cations can also be drawn for the $\left[\mathrm{YCl}_{6}\right]^{3-}$ and $\left[\mathrm{LaI}_{6}\right]^{3-}$ salts. The structures of $[\mathrm{EDMIM}]_{3}\left[\mathrm{YCl}_{6}\right]$ and $[\mathrm{EDMIM}]_{3}\left[\mathrm{LaI}_{6}\right]$ are shown in Fig. 7 and 8 , respectively.

$[\mathrm{EDMIM}]_{3}\left[\mathrm{YCl}_{6}\right]$ and $[\mathrm{EDMIM}]_{3}\left[\mathrm{LaCl}_{6}\right]$ are isomorphous and isostructural, whereas $[\mathrm{EMIM}]_{3}\left[\mathrm{YCl}_{6}\right]$ and $[\mathrm{EMIM}]_{3}\left[\mathrm{LaCl}_{6}\right]$ crystallise in different space groups. This suggests that the hydrogen bonding interactions play a greater role in the crystal packing arrangements for the $[\mathrm{EMIM}]^{+}$salts. The $\mathrm{C} \cdot \mathrm{Cl}(\mathrm{H} 4 / \mathrm{H} 5)$ distances (Table 3) are not notably different between $[\mathrm{EMIM}]_{3}\left[\mathrm{YCl}_{6}\right]$ and $[\mathrm{EDMIM}]_{3}\left[\mathrm{YCl}_{6}\right]$.

For $[\mathrm{EDMIM}]_{3}\left[\mathrm{LaI}_{6}\right]$ two different $\left[\mathrm{LaX}_{6}\right]^{3-}$ environments are apparent, with one iodine acting as an acceptor to five different donor hydrogens. However, the C - - I distances (Table 3) are not notably different between the EMIM and EDMIM compounds.

\section{Spectroscopic characterisation and comparisons}

In keeping with our previous observations for $\left[\mathrm{GeCl}_{6}\right]^{2-}$ anions, ${ }^{3}$ the chemical shift of the $\mathrm{H} 2$ proton in the ${ }^{1} \mathrm{H}$ NMR spectrum was used to indicate the strength of the hydrogen bonding in solution (Table 4).

From the NMR data it is apparent that the chemical shift of the signal associated with the $\mathrm{H} 2$ proton shifts to low frequency for the heavier halides. This correlates with decreasing strength of the solution phase hydrogen bonding interactions upon changing from $\mathrm{Cl}$ to $\mathrm{I}$. The chemical shifts of the less acidic $\mathrm{H} 4 / 5$ protons are not affected by changing the halide, suggesting that the salts are completely dissociated in solution. This is consistent with the trend observed for [EMIM] $\left[\mathrm{GeX}_{3}\right](\mathrm{X}=\mathrm{Cl}, \mathrm{Br}, \mathrm{I}){ }^{3}$

For the $\left[\mathrm{MX}_{6}\right]^{3-}$ salts, ${ }^{45} \mathrm{Sc},{ }^{89} \mathrm{Y}$ and ${ }^{139} \mathrm{La}$ NMR spectra were also obtained (Table 5). All complexes were soluble in MeCN at approximate 10-15 mM concentration. The $\left[\mathrm{N}^{n} \mathrm{Bu}_{4}\right]^{+}$salt was soluble at a similar concentration in $\mathrm{CH}_{2} \mathrm{Cl}_{2}$, whereas the 

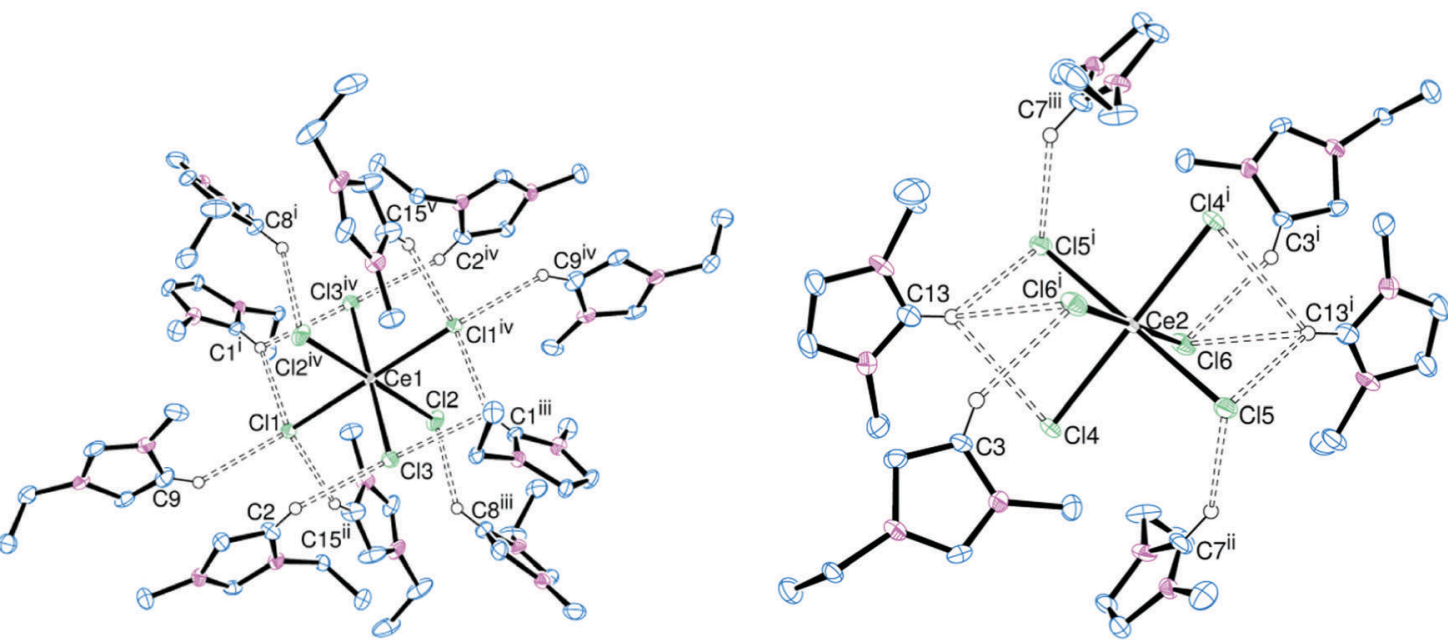

Fig. 5 ORTEP representation of $\left[\mathrm{EMIM}_{3}\left[\mathrm{CeCl}_{6}\right]\right.$ showing the hydrogen bonding (dotted lines) surrounding the Ce1-centred cation (left) and the Ce2centred cation (right). Displacement ellipsoids are drawn at the 50\% probability level and $\mathrm{H}$ atoms not involved in hydrogen bonding are omitted for clarity. Selected bond lengths (Å): Ce1-Cl1 2.7872(16), Ce1-Cl2 2.7514(17), Ce1-Cl3 2.7738(16), Ce2-Cl4 2.7755(17), Ce2-Cl5 2.7752(17), Ce2Cl6 2.7722(17). Symmetry codes: (i) $-x,-y,-z$; (ii) $-1-x,-y, 1-z$; (iii) $-x, 0.5+y, 0.5-z$; (iv) $x,-0.5-y, 0.5+z$; (v) $-x, y-0.5,0.5-z$.

Table 2 Hydrogen bond data for the $[\mathrm{EMIM}]_{3}\left[\mathrm{MCl}_{6}\right]$ series of compounds prepared in this study

\begin{tabular}{|c|c|c|c|c|c|c|}
\hline & \multicolumn{2}{|c|}{$[\mathrm{EMIM}]_{3}\left[\mathrm{ScCl}_{6}\right]$} & \multicolumn{2}{|c|}{$[\mathrm{EMIM}]_{3}\left[\mathrm{YCl}_{6}\right]$} & \multicolumn{2}{|c|}{$\underline{\mathrm{EMIM}}]_{3}\left[\mathrm{CeCl}_{6}\right]$} \\
\hline & $\begin{array}{l}\text { Length } \\
(\AA)\end{array}$ & $\begin{array}{l}\text { Angle } \\
\left({ }^{\circ}\right)\end{array}$ & $\begin{array}{l}\text { Length } \\
(\AA)\end{array}$ & $\begin{array}{l}\text { Angle } \\
\left({ }^{\circ}\right)\end{array}$ & $\begin{array}{l}\text { Length } \\
\text { (A) }\end{array}$ & $\begin{array}{l}\text { Angle } \\
\left(^{\circ}\right)\end{array}$ \\
\hline \multirow{5}{*}{$\overline{\mathrm{C} \cdots \mathrm{X}(\mathrm{H} 2)}$} & $3.506(3)$ & 149.5 & $3.547(4)$ & 146.6 & $3.547(7)$ & 150.8 \\
\hline & $3.496(3)$ & 131.3 & $3.531(5)$ & 130.0 & $3.425(7)$ & 132.4 \\
\hline & $3.407(3)$ & 138.1 & $3.422(5)$ & 135.9 & $3.333(7)$ & 117.1 \\
\hline & $3.604(3)$ & 135.2 & $3.650(4)$ & 134.6 & $3.569(8)$ & 141.9 \\
\hline & $3.548(3)$ & 146.8 & $3.588(5)$ & 145.0 & & \\
\hline \multirow[t]{5}{*}{$\mathrm{C} \cdots \mathrm{X}(\mathrm{H} 4 / 5)$} & $3.586(3)$ & 166.7 & $3.584(5)$ & 165.0 & $3.568(7)$ & 150.4 \\
\hline & $3.692(3)$ & 152.5 & $3.695(4)$ & 153.1 & $3.583(7)$ & 143.2 \\
\hline & $3.604(3)$ & 135.6 & $3.604(5)$ & 135.8 & $3.622(8)$ & 142.7 \\
\hline & $3.434(3)$ & 131.7 & $3.459(4)$ & 128.6 & $3.542(8)$ & 147.2 \\
\hline & $3.383(3)$ & 135.1 & $3.365(5)$ & 136.2 & $3.512(7)$ & 139.7 \\
\hline
\end{tabular}

$[\mathrm{EMIM}]^{+}$, [BMPYRR $]^{+}$and $[\mathrm{EDMIM}]^{+}$salts were poorly soluble in $\mathrm{CH}_{2} \mathrm{Cl}_{2}$. For the $\left[\mathrm{LaCl}_{6}\right]^{3-}$ salts a small high frequency shift in $\delta^{139} \mathrm{La}$ occurs as the cation changes along the series: $\left[\mathrm{N}^{n} \mathrm{Bu}_{4}\right]^{+} \rightarrow$ $[\mathrm{BMPYRR}]^{+} \rightarrow[\mathrm{EDMIM}]^{+} \rightarrow[\mathrm{EMIM}]^{+}$in both $\mathrm{MeCN}$ and $\mathrm{CH}_{2} \mathrm{Cl}_{2}$ solution, but given the large ${ }^{139} \mathrm{La}$ NMR chemical shift range, these differences may not be significant. The ${ }^{139} \mathrm{La}$ NMR resonance shifts to high frequency as the halide becomes heavier; the $\left[\mathrm{LaI}_{6}\right]^{3-}$ system showing a very broad resonance at $\sim 1400 \mathrm{ppm}$ $\left(W_{1 / 2} \sim 12000 \mathrm{~Hz}\right)$. The yttrium salts show no ${ }^{89} \mathrm{Y}$ NMR resonance at room temperature in $\mathrm{MeCN}$, presumably due to chloride exchange. However, cooling to $233 \mathrm{~K}$ reveals a sharp singlet for each compound.

\section{Conclusions}

All of the salts are based upon six-coordinate $\left[\mathrm{MX}_{6}\right]^{3-}$ units, and for those containing EMIM and EDMIM cations, significant $\mathrm{C}-\mathrm{H} \cdots \mathrm{X}$ hydrogen-bonding interactions to the substituted imidazolium cations are evident from crystallographic studies.

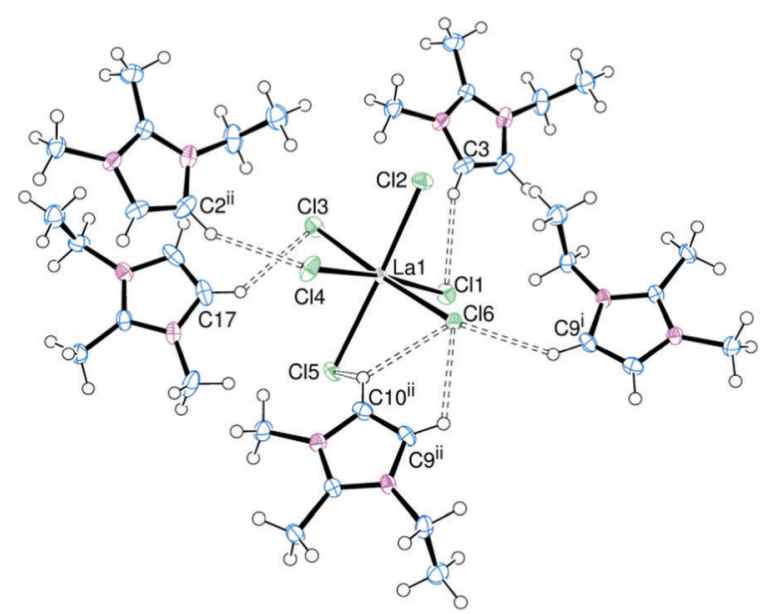

Fig. 6 ORTEP representation of $[E D M I M]_{3}\left[\mathrm{LaCl}_{6}\right]$ showing the hydrogen bonding (dotted lines). Displacement ellipsoids are drawn at the 50\% probability level. Selected bond lengths (Å): La-Cl1 2.7963(7), La-Cl2 2.7582(6), La-Cl3 2.8029(6), La-Cl4 2.7950(7), La-Cl5 2.8262(6), La-Cl6 2.7742(5). Symmetry codes: (i) $1-x, 1-y, 1-z$; (ii) $x-1, y, z$.

The shortest $\mathrm{C} \cdots \mathrm{X}$ distances for the $[\mathrm{EMIM}]_{3}\left[\mathrm{MX}_{6}\right]$ series involve the NCN (H2) proton, with much weaker interactions to the $\mathrm{H} 4 / \mathrm{H} 5$ protons. Despite the decreased charge : radius ratio along the series from Sc to $\mathrm{Y}$ to $\mathrm{La}$, the hydrogen bonds through $\mathrm{H} 4 / 5$ are unaffected. However, there is a small increase in the hydrogen bond lengths involving $\mathrm{H} 2$ along the same series.

Substitution of the $\mathrm{H} 2$ proton with a Me group in the EDMIM cation has a significant influence on the cation-anion interactions in the solid state. The structure of $[\mathrm{EDMIM}]_{3}\left[\mathrm{LaCl}_{6}\right]$ revealed five associated $[\mathrm{EDMIM}]^{+}$cations and the $\mathrm{C} \cdots \mathrm{Cl}$ distances involving $\mathrm{H} 4 / \mathrm{H} 5$ were shorter than those for $[\mathrm{EMIM}]_{3}\left[\mathrm{LaCl}_{6}\right]$.

The solution ${ }^{1} \mathrm{H}$ NMR trends indicate that the hydrogen bonding to the EMIM (H2) cations becomes weaker as the 


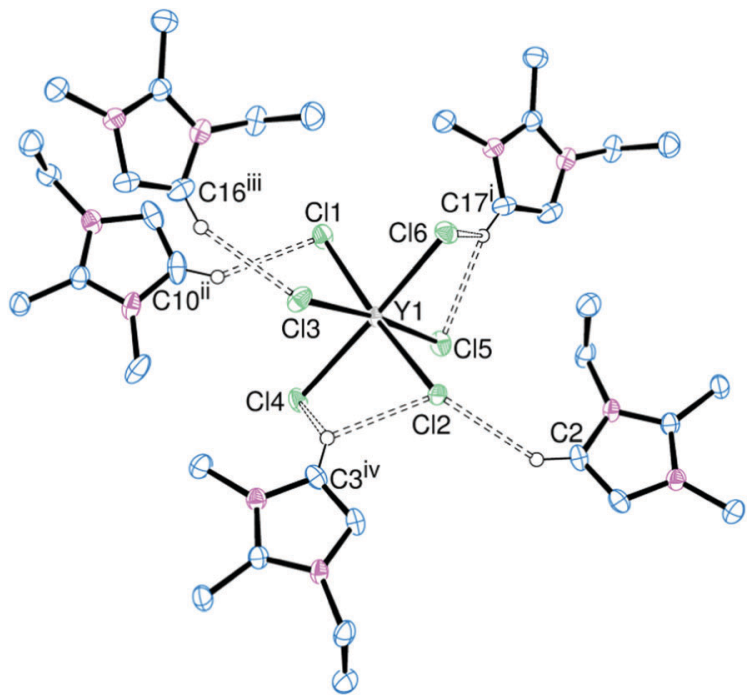

Fig. 7 ORTEP representation of $[E D M I M]_{3}\left[\mathrm{YCl}_{6}\right]$ showing the hydrogen bonding (dotted lines). Displacement ellipsoids are drawn at the 50\% probability level and hydrogen atoms not involved in hydrogen bonding are omitted for clarity. Selected bond lengths (Å): Y-Cl1 2.6580(5), $\mathrm{Y}-\mathrm{Cl} 2$ 2.6398(5), $\mathrm{Y}-\mathrm{Cl} 3$ 2.6496(5), Y-Cl4 2.6800(5), Y-Cl5 2.6464(5), Y-Cl6 2.6167(5). Symmetry codes: (i) $-x, 2-y_{1}-z$; (ii) $x+0.5,1.5-y$, $z-0.5$; (iii) $-x, 1-y,-z$; (iv) $1-x, 1-y,-z$.

halide becomes heavier, while the EDMIM salts appear to be completely dissociated in solution.

\section{Experimental}

All preparations were carried out using standard Schlenk techniques under a $\mathrm{N}_{2}$ atmosphere. Anhydrous $\mathrm{MCl}_{3}(\mathrm{M}=\mathrm{La}, \mathrm{Ce})$ were obtained by reacting hydrated $\mathrm{MCl}_{3}$ (Sigma) with excess $\mathrm{SOCl}_{2}$, then drying in vacuo. Anhydrous $\mathrm{ScCl}_{3}, \mathrm{YCl}_{3}, \mathrm{LaBr}_{3}$ and $\mathrm{LaI}_{3}$ were obtained from Alfa and used as received. [EMIM]X $(\mathrm{X}=\mathrm{Cl}, \mathrm{Br}, \mathrm{I})$, $[\mathrm{EDMIM}] \mathrm{Cl},\left[\mathrm{N}^{n} \mathrm{Bu}_{4}\right] \mathrm{Cl}$ and $[\mathrm{BMPYRR}] \mathrm{Cl}$ were obtained from Sigma, dried in vacuo at $100{ }^{\circ} \mathrm{C}$ for 4 hours and stored in a glove box. [EDMIM]I was prepared by stirring a solution of [EDMIM]Cl and $\mathrm{NaI}$ in water for 4 hours, then extracting into $\mathrm{CH}_{2} \mathrm{Cl}_{2}$ followed by drying in vacuo at $100{ }^{\circ} \mathrm{C}$ for 4 hours. $\mathrm{MeCN}$ and $\mathrm{CH}_{2} \mathrm{Cl}_{2}$ were dried prior to use from $\mathrm{CaH}_{2}$. Infrared spectra were recorded as Nujol mulls between CsI plates using a Perkin-Elmer Spectrum 100 spectrometer over the range $4000-200 \mathrm{~cm}^{-1}$. Raman spectra were recorded from powdered solid samples using a PerkinElmer FT-Raman $2000 \mathrm{R}$ with a Nd:YAG laser. ${ }^{1} \mathrm{H}$ NMR spectra were recorded in $\mathrm{CD}_{2} \mathrm{Cl}_{2}$ and $\mathrm{CD}_{3} \mathrm{CN}$ using a Bruker DPX400 spectrometer and are referenced to the residual protio solvent. ${ }^{45} \mathrm{Sc},{ }^{89} \mathrm{Y}$ and ${ }^{139} \mathrm{La}$ NMR spectra were also recorded in $\mathrm{CD}_{2} \mathrm{Cl}_{2}$ or $\mathrm{CD}_{3} \mathrm{CN}$ on a Bruker DPX400 spectrometer and are referenced to $0.1 \mathrm{~mol} \mathrm{dm}^{-3}$ solutions of the chlorides in $\mathrm{D}_{2} \mathrm{O}$ solutions at $\mathrm{pH}=1$. For yttrium-89 NMR spectra a $3 \mathrm{~s}$ pulse delay was used and TEMPO (2,2,6,6-tetramethylpiperidine-oxyl) was added as relaxation agent. Microanalyses were undertaken by Medac Ltd or London Metropolitan University.

\section{Preparations}

$\left[\mathbf{N}^{n} \mathbf{B u}_{4}\right]_{3}\left[\mathbf{L a C l}_{6}\right] \cdot \mathrm{LaCl}_{3}(100 \mathrm{mg}, 0.408 \mathrm{mmol})$ was suspended in dichloromethane $(10 \mathrm{~mL})$ in a Schlenk flask and a solution of $\left[\mathrm{N}^{n} \mathrm{Bu}_{4}\right] \mathrm{Cl}(396 \mathrm{mg}, 1.43 \mathrm{mmol})$ in acetone $(10 \mathrm{~mL})$ added. The mixture was stirred until all the solids had dissolved. Diethyl ether $(20 \mathrm{~mL})$ was added slowly and a white solid precipitated which was filtered and dried under vacuum. Yield: $345 \mathrm{mg}$, 79\%. Raman (solid): $262 \mathrm{~cm}^{-1}\left(\mathrm{~A}_{1 \mathrm{~g}}\left[\mathrm{LaCl}_{6}\right]^{3-}\right) .{ }^{1} \mathrm{H}$ NMR $\left(\mathrm{CD}_{3} \mathrm{CN}, 300 \mathrm{~K}\right): \delta=$ 3.08-3.14 (m, [2H]), 1.55-1.66 (m, [2H]), 1.30-1.42 (m, [2H]), 0.97 $(\mathrm{t}, J=7.35 \mathrm{~Hz},[3 \mathrm{H}]) \cdot{ }^{139} \mathrm{La} \mathrm{NMR}\left(\mathrm{CH}_{3} \mathrm{CN} / \mathrm{CD}_{3} \mathrm{CN}, 300 \mathrm{~K}\right): \delta=846$ (s, $W_{1 / 2}=800 \mathrm{~Hz}$ ). Anal. required for $\mathrm{C}_{48} \mathrm{H}_{108} \mathrm{Cl}_{6} \mathrm{LaN}_{3}$ : C, 53.43; H, 10.09; N, 3.89\%. Found: C, 53.29; H, 9.92; N, 4.04\%.

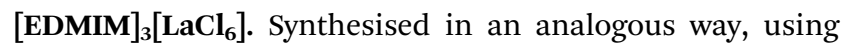
$\mathrm{LaCl}_{3}(100 \mathrm{mg}, 0.408 \mathrm{mmol})$ and [EDMIM]Cl (197 mg, $\left.1.22 \mathrm{mmol}\right)$. White crystalline product. Yield: $213 \mathrm{mg}, 72 \%$. Raman (solid): $244 \mathrm{~cm}^{-1}\left(\mathrm{~A}_{1 \mathrm{~g}}\left[\mathrm{LaCl}_{6}\right]^{3-}\right){ }^{1} \mathrm{H}$ NMR $\left(\mathrm{CD}_{3} \mathrm{CN}, 300 \mathrm{~K}\right): \delta=7.36$
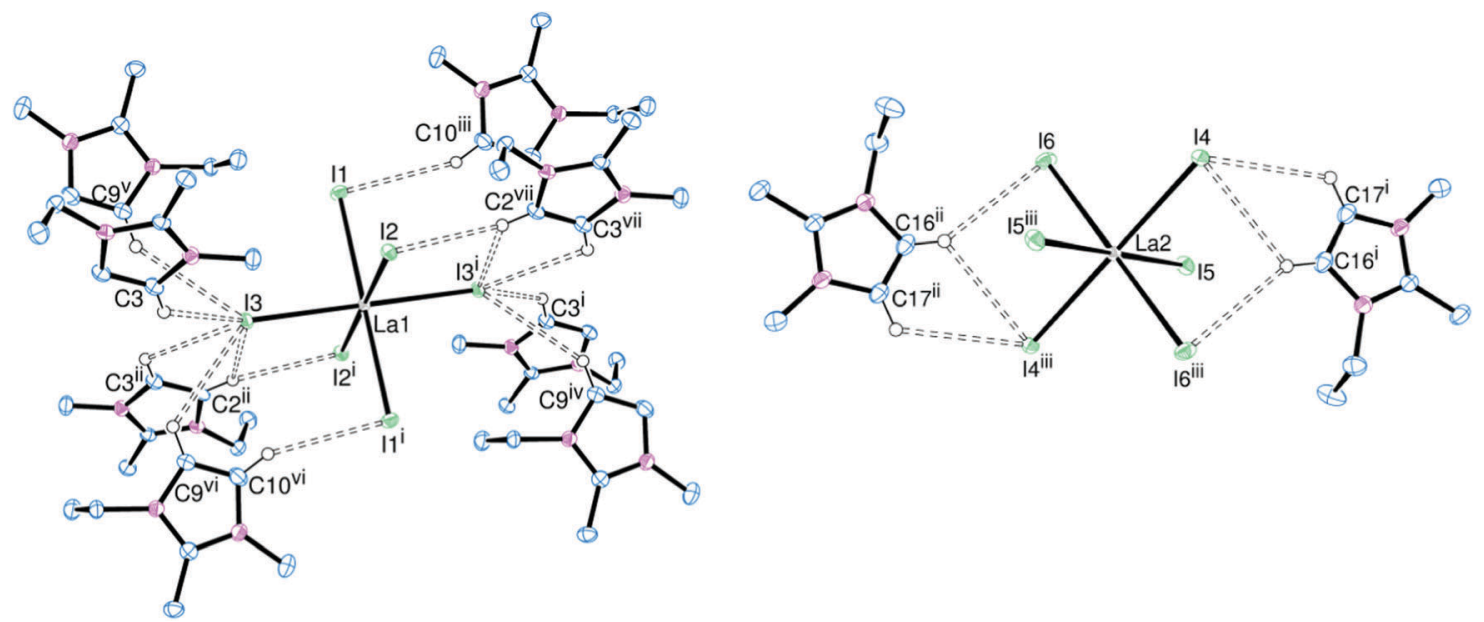

Fig. 8 ORTEP representation of [EDMIM $]_{3}\left[\mathrm{Lal}_{6}\right]$ showing the hydrogen bonding (dotted lines) surrounding the La1-centred cation (left) and the La2centred cation (right). Displacement ellipsoids are drawn at the 50\% probability level and $\mathrm{H}$ atoms not involved in hydrogen bonding are omitted for clarity. Selected bond lengths (Å): La1-I1 3.1800(7), La1-12 3.1545(6), La1-13 3.1903(7), La2-14 3.1779(5), La2-15 3.1566(5), La2-16 3.1870(5). Symmetry codes: (i) $1-x,-y, 1-z$; (ii) $-x,-1-y,-z$; (iii) $x, y-1, z$; (iv) $-x,-1-y, 1-z$; (v) $1-x,-1-y, 1-z$; (vi) $x, y, 1+z$; (vii) $x, 1+y, z$. 
Table 3 Hydrogen bond data for $[\mathrm{EDMIM}]_{3}\left[\mathrm{YCl}_{6}\right]$, [EDMIM$]_{3}\left[\mathrm{LaCl}_{6}\right]$ and $\left[\mathrm{EDMIM}_{3}\left[\mathrm{Lal}_{6}\right]\right.$

\begin{tabular}{|c|c|c|c|c|c|c|}
\hline & \multicolumn{2}{|c|}{$[\mathrm{EDMIM}]_{3}\left[\mathrm{YCl}_{6}\right]$} & \multicolumn{2}{|c|}{$[\mathrm{EDMIM}]_{3}\left[\mathrm{LaCl}_{6}\right]$} & \multicolumn{2}{|c|}{$[\mathrm{EDMIM}]_{3}\left[\mathrm{LaI}_{6}\right]$} \\
\hline & $\begin{array}{l}\text { Length } \\
(\AA)\end{array}$ & $\begin{array}{l}\text { Angle } \\
\left({ }^{\circ}\right)\end{array}$ & $\begin{array}{l}\text { Length } \\
(\AA)\end{array}$ & $\begin{array}{l}\text { Angle } \\
\left({ }^{\circ}\right)\end{array}$ & $\begin{array}{l}\text { Length } \\
(\AA)\end{array}$ & $\begin{array}{l}\text { Angle } \\
\left({ }^{\circ}\right)\end{array}$ \\
\hline \multirow[t]{7}{*}{$\mathrm{C} \cdots \mathrm{X}(\mathrm{H} 4 / 5)$} & $3.542(2)$ & 142.4 & $3.580(2)$ & 149.6 & $3.948(3)$ & 118.8 \\
\hline & $3.693(2)$ & 123.8 & $3.515(2)$ & 136.6 & $3.956(3)$ & 118.5 \\
\hline & $3.388(2)$ & 129.8 & $3.521(2)$ & 148.9 & $3.933(3)$ & 139.2 \\
\hline & $3.482(2)$ & 145.1 & $3.686(2)$ & 122.5 & $3.775(3)$ & 125.2 \\
\hline & $3.520(2)$ & 149.9 & $3.455(2)$ & 125.8 & $3.883(3)$ & 124.3 \\
\hline & $3.544(2)$ & 150.2 & $3.601(2)$ & 112.0 & $3.892(3)$ & 124.8 \\
\hline & $3.577(2)$ & 122.6 & $3.524(2)$ & 143.0 & $3.883(3)$ & 115.3 \\
\hline
\end{tabular}

Table 4 Effect of $\left[\mathrm{MX}_{6}\right]^{3-}$ on the $\mathrm{N}-\mathrm{CH}-\mathrm{N}{ }^{1} \mathrm{H}$ NMR shift in $\mathrm{CD}_{3} \mathrm{CN}$ solution

\begin{tabular}{lll}
\hline & $\delta\left({ }^{1} \mathrm{H}\right)^{a} / \mathrm{ppm}$ & \\
\cline { 2 - 3 } Compound & $\mathrm{N}-\mathrm{CH}-\mathrm{N}$ & $\Delta^{b}$ \\
\hline$[\mathrm{EMIM}]_{3}\left[\mathrm{LaCl}_{6}\right]$ & 9.27 & +0.45 \\
{$[\mathrm{EMIM}]_{3}\left[\mathrm{LaBr}_{6}\right]$} & 8.93 & +0.11 \\
{$[\mathrm{EMIM}]_{3}\left[\mathrm{LaI}_{6}\right]$} & 8.61 & -0.21 \\
{$[\mathrm{EMIM}]_{3}\left[\mathrm{CeCl}_{6}\right]$} & 9.77 & +0.95 \\
{$[\mathrm{EMIM}]_{3}\left[\mathrm{YCl}_{6}\right]$} & 9.26 & +0.44 \\
{$[\mathrm{EMIM}]_{3}\left[\mathrm{ScCl}_{6}\right]$} & 9.41 & +0.59 \\
{$[\mathrm{EMIM}] \mathrm{Cl}$} & 8.82 & - \\
{$[\mathrm{EMIM}] \mathrm{Br}$} & 8.84 & -
\end{tabular}

${ }^{a} 6.8 \mathrm{mM}$ solutions in $\mathrm{CD}_{3} \mathrm{CN} .{ }^{b}$ Change in shift compared with [EMIM] $\mathrm{Cl}$ at the same concentration in $\mathrm{CD}_{3} \mathrm{CN}$.

Table 5 Selected NMR spectroscopic data for [CATION $]_{3}\left[\mathrm{MX}_{6}\right]$

\begin{tabular}{|c|c|c|c|c|}
\hline \multirow[b]{2}{*}{ Salt } & $\delta(\mathrm{ppm})$ & $W_{1 / 2}(\mathrm{~Hz})$ & $\delta(\mathrm{ppm})$ & $W_{1 / 2}(\mathrm{~Hz})$ \\
\hline & \multicolumn{2}{|l|}{$\mathrm{MeCN}$} & \multicolumn{2}{|l|}{$\mathrm{CH}_{2} \mathrm{Cl}_{2}$} \\
\hline$\left[\mathrm{N}^{n} \mathrm{Bu}_{4}\right]_{3}\left[\mathrm{LaCl}_{6}\right]$ & 846 & 800 & 872 & 1200 \\
\hline$[\mathrm{BMPYRR}]_{3}\left[\mathrm{LaCl}_{6}\right]$ & 855 & 500 & 880 & 300 \\
\hline$[\mathrm{EDMIM}]_{3}\left[\mathrm{LaCl}_{6}\right]$ & 864 & 600 & n.o. ${ }^{b}$ & - \\
\hline$[\mathrm{EMIM}]_{3}\left[\mathrm{LaCl}_{6}\right]$ & 867 & 400 & 892 & 300 \\
\hline$[\mathrm{EMIM}]_{3}\left[\mathrm{LaBr}_{6}\right]$ & 1095 & 1200 & n.o. ${ }^{b}$ & - \\
\hline$[\mathrm{EMIM}]_{3}\left[\mathrm{LaI}_{6}\right]$ & $\sim 1400$ & 12000 & n.o. ${ }^{b}$ & - \\
\hline$[\mathrm{EMIM}]_{3}\left[\mathrm{YCl}_{6}\right]^{a}$ & 407 & - & - & - \\
\hline$[\mathrm{EDMIM}]_{3}\left[\mathrm{YCl}_{6}\right]^{a}$ & 401 & - & - & - \\
\hline$[\mathrm{EMIM}]_{3}\left[\mathrm{ScCl}_{6}\right]$ & 254 & 170 & - & - \\
\hline
\end{tabular}

${ }^{a}$ Spectrum recorded at 233 K. ${ }^{b}$ n.o. = not observed due to low solubility.

(s, [2H]), $4.12(\mathrm{q}, J=7.16 \mathrm{~Hz},[2 \mathrm{H}]), 3.75(\mathrm{~s},[3 \mathrm{H}]), 2.54(\mathrm{~s},[3 \mathrm{H}])$, $1.39(\mathrm{t}, J=7.34 \mathrm{~Hz},[3 \mathrm{H}]),\left(\mathrm{CD}_{2} \mathrm{Cl}_{2}, 300 \mathrm{~K}\right): \delta=7.64(\mathrm{~d}, J=2.20 \mathrm{~Hz}$, $[\mathrm{H}]), 7.46(\mathrm{~d}, J=2.20 \mathrm{~Hz},[\mathrm{H}]), 4.23(\mathrm{q}, J=7.5 \mathrm{~Hz},[2 \mathrm{H}]), 3.97$ $(\mathrm{s},[3 \mathrm{H}]) 2.75(\mathrm{~s},[3 \mathrm{H}]), 1.50(\mathrm{t}, J=7.34 \mathrm{~Hz},[3 \mathrm{H}]) .{ }^{139} \mathrm{La} \mathrm{NMR}$ $\left(\mathrm{CH}_{3} \mathrm{CN} / \mathrm{CD}_{3} \mathrm{CN}\right): \delta=864\left(\mathrm{~s}, W_{1 / 2}=600 \mathrm{~Hz}\right)$. Anal. required for $\mathrm{C}_{21} \mathrm{H}_{39} \mathrm{Cl}_{6} \mathrm{LaN}_{6}$ : C, 34.68; $\mathrm{H}, 5.41 ; \mathrm{N}, 11.56 \%$. Found: $\mathrm{C}, 34.55 ; \mathrm{H}$, $5.34 ; \mathrm{N}, 11.45 \%$.

[BMPYRR $]_{3}\left[\mathrm{LaCl}_{6}\right] \cdot \mathrm{LaCl}_{3}(100 \mathrm{mg}, 0.407 \mathrm{mmol})$ was suspended in $\mathrm{MeCN}(10 \mathrm{~mL})$ and a solution of [BMPYRR]Cl, $(255 \mathrm{mg}$, $1.43 \mathrm{mmol})$ in MeCN $(10 \mathrm{~mL})$ was added. The mixture was heated briefly and then stirred for one hour. The resulting suspension was filtered and diethyl ether $(10 \mathrm{~mL})$ was added to the filtrate, leading to the precipitation of a fine white crystalline product. The solvent was removed via cannula and the solid was dried under vacuum.
Yield: $245 \mathrm{mg}, 77 \%$. Raman (solid): $240 \mathrm{~cm}^{-1}\left(\mathrm{~A}_{1 \mathrm{~g}}\left[\mathrm{LaCl}_{6}\right]^{3-}\right)$. ${ }^{1} \mathrm{H}$ NMR $\left(\mathrm{CD}_{3} \mathrm{CN}, 300 \mathrm{~K}\right): \delta=3.44-3.59(\mathrm{~m},[4 \mathrm{H}]), 3.30-3.35$ (m, $[2 \mathrm{H}]), 3.03(\mathrm{~s},[3 \mathrm{H}]), 2.18$ (br. $\mathrm{s},[4 \mathrm{H}]), 1.68-1.78$ (m, $[2 \mathrm{H}]$ ), 1.32-1.45 (m, $[2 \mathrm{H}]), 0.96(\mathrm{t}, J=7.35 \mathrm{~Hz},[3 \mathrm{H}]) .{ }^{139} \mathrm{La} \mathrm{NMR}$ $\left(\mathrm{CH}_{3} \mathrm{CN} / \mathrm{CD}_{3} \mathrm{CN}\right): \delta=855\left(\mathrm{~s}, W_{1 / 2}=500 \mathrm{~Hz}\right)$. Anal. required for $\mathrm{C}_{27} \mathrm{H}_{60} \mathrm{Cl}_{6} \mathrm{LaN}_{3}: \mathrm{C}, 41.66 ; \mathrm{H}, 7.77 ; \mathrm{N}, 5.40 \%$. Found: C, 41.81; $\mathrm{H}, 7.63 ; \mathrm{N}, 5.50 \%$.

$[\mathbf{E M I M}]_{3}\left[\mathrm{LaCl}_{6}\right] \cdot \mathrm{LaCl}_{3}(100 \mathrm{mg}, 0.408 \mathrm{mmol})$ was suspended in MeCN (5 mL) and a solution of [EMIM]Cl, $(210 \mathrm{mg}$, $1.43 \mathrm{mmol})$ in MeCN $(5 \mathrm{~mL})$ was added. The mixture was heated briefly and then stirred for 1 hour. The resulting suspension was filtered and diethyl ether $(10 \mathrm{~mL})$ was added to the filtrate, leading to the precipitation of a white crystalline product. This was allowed to settle, the solvent removed via cannula and the solid was then dried under vacuum. Yield: $185 \mathrm{mg}, 66 \%$. Raman: $240 \mathrm{~cm}^{-1}\left(\mathrm{~A}_{1 \mathrm{~g}}\left[\mathrm{LaCl}_{6}\right]^{3-}\right) .{ }^{1} \mathrm{H} \mathrm{NMR}$ $\left(\mathrm{CD}_{3} \mathrm{CN}, 300 \mathrm{~K}\right): \delta=9.27(\mathrm{~s},[\mathrm{H}]), 7.39(\mathrm{~s},[\mathrm{H}]), 7.34(\mathrm{~s},[\mathrm{H}])$, $4.33(\mathrm{q}, J=7.16 \mathrm{~Hz},[2 \mathrm{H}]), 3.96(\mathrm{~s},[3 \mathrm{H}]), 1.46(\mathrm{t}, J=7.16 \mathrm{~Hz}$, $[3 \mathrm{H}]) .{ }^{139} \mathrm{La} \mathrm{NMR}\left(\mathrm{CH}_{3} \mathrm{CN} / \mathrm{CD}_{3} \mathrm{CN}\right): \delta=867\left(\mathrm{~s}, W_{1 / 2}=400 \mathrm{~Hz}\right)$. Anal. required for $\mathrm{C}_{18} \mathrm{H}_{33} \mathrm{Cl}_{6} \mathrm{LaN}_{6}: \mathrm{C}, 31.56 ; \mathrm{H}, 4.85 ; \mathrm{N}, 12.27 \%$. Found: C, 31.31; H, 4.67; N, 12.07\%.

[EMIM $]_{3}\left[\mathbf{L a B r}_{6}\right]$. Synthesised in an analogous way, using $\mathrm{LaBr}_{3}(100 \mathrm{mg}, 0.264 \mathrm{mmol}$ ) and [EMIM]Br (151 mg, $0.792 \mathrm{mmol})$. White solid. Yield: $143 \mathrm{mg}, 57 \% .{ }^{1} \mathrm{H}$ NMR $\left(\mathrm{CD}_{3} \mathrm{CN}, 300 \mathrm{~K}\right): 8.93$ (s, [H]), 7.42 (s, [H]), 7.37 (s, [H]) 4.27 (q, $J=7.34 \mathrm{~Hz},[2 \mathrm{H}]), 3.91$ (s, [3H]), 1.47 (t, $J=7.34 \mathrm{~Hz},[3 \mathrm{H}]) .{ }^{139} \mathrm{La}$ NMR $\left(\mathrm{CH}_{3} \mathrm{CN} / \mathrm{CD}_{3} \mathrm{CN}\right.$, $300 \mathrm{~K}): \delta=1095\left(\mathrm{~s}, W_{1 / 2}=1200 \mathrm{~Hz}\right)$. Anal. required for $\mathrm{C}_{18} \mathrm{H}_{33} \mathrm{Br}_{6} \mathrm{LaN}_{6}: \mathrm{C}, 22.71 ; \mathrm{H}, 3.49 ; \mathrm{N}, 8.83 \%$. Found: $\mathrm{C}, 22.57 ; \mathrm{H}$, $3.39 ; \mathrm{N}, 8.74 \%$.

$[\mathbf{E M I M}]_{3}\left[\mathbf{L a I}_{6}\right]$. Synthesised in an analogous way, using $\mathrm{LaI}_{3}$ (150 mg, $0.289 \mathrm{mmol}$ ) and [EMIM]I (240 mg, $1.01 \mathrm{mmol})$. After filtering, the solvent volume was reduced to approximately $25 \%$ and diethyl ether was added. Large colourless crystals suitable for X-ray diffraction were grown overnight. Yield: $180 \mathrm{mg}, 46 \%$. ${ }^{1} \mathrm{H}$ NMR $\left(\mathrm{CD}_{3} \mathrm{CN}, 300 \mathrm{~K}\right): \delta=8.61(\mathrm{~s},[\mathrm{H}]), 7.41(\mathrm{~s},[\mathrm{H}]) 7.36$ (s, [H]) 4.19 (q, $J=7.16 \mathrm{~Hz},[2 \mathrm{H}]), 3.84(\mathrm{~s},[3 \mathrm{H}]), 1.46(\mathrm{t}, J=$ $7.35 \mathrm{~Hz},[3 \mathrm{H}])$. Raman: $110 \mathrm{~cm}^{-1}\left(\mathrm{~A}_{1 \mathrm{~g}}\left[\mathrm{LaI}_{6}\right]^{3-}\right)$. Anal. required for $\mathrm{C}_{18} \mathrm{H}_{33} \mathrm{I}_{6} \mathrm{LaN}_{6}$ : C, 17.52; H, 2.70; N, 6.81\%. Found: C, 17.38; $\mathrm{H}, 2.65 ; \mathrm{N}, 6.94 \%$.

$[\text { EDMIM }]_{3}\left[\mathbf{L a I}_{\mathbf{6}}\right]$. Synthesised in an analogous way. Yield: $55 \%$. White crystalline solid. ${ }^{1} \mathrm{H}$ NMR $\left(\mathrm{CD}_{3} \mathrm{CN}, 300 \mathrm{~K}\right): \delta=$ $7.36(\mathrm{~d},[2 \mathrm{H}], J=1.96 \mathrm{~Hz}), 4.08(\mathrm{q}, J=7.34 \mathrm{~Hz},[2 \mathrm{H}]), 3.70$ $(\mathrm{s},[3 \mathrm{H}]), 2.51(\mathrm{~s},[3 \mathrm{H}]), 1.38(\mathrm{t}, J=7.34 \mathrm{~Hz},[3 \mathrm{H}])$. Anal. required for $\mathrm{C}_{21} \mathrm{H}_{39} \mathrm{I}_{6} \mathrm{LaN}_{6}$ : C, 19.77; H, 3.08; N, 6.59\%. Found: C, 19.60; $\mathrm{H}, 3.15 ; \mathrm{N}, 6.39 \%$.

$[\mathbf{E M I M}]_{3}\left[\mathrm{CeCl}_{6}\right]$. Synthesised in an analogous way, using $\mathrm{CeCl}_{3}(100 \mathrm{mg}, 0.406 \mathrm{mmol})$ and [EMIM]Cl (208 mg, $\left.1.42 \mathrm{mmol}\right)$, forming a white crystalline product. Yield: $175 \mathrm{mg}, 63 \%$. Raman (solid): $244 \mathrm{~cm}^{-1}\left(\mathrm{~A}_{1 \mathrm{~g}}\left[\mathrm{CeCl}_{6}\right]^{3-}\right) .{ }^{1} \mathrm{H}$ NMR $\left(\mathrm{CD}_{3} \mathrm{CN}, 300 \mathrm{~K}\right): \delta=$ $9.77(\mathrm{~s},[\mathrm{H}]), 7.45(\mathrm{~s},[\mathrm{H}]), 7.40(\mathrm{~s},[\mathrm{H}]), 4.44(\mathrm{q}, J=7.2 \mathrm{~Hz},[2 \mathrm{H}])$, $4.01(\mathrm{~s},[3 \mathrm{H}]), 1.51(\mathrm{t}, J=6.6 \mathrm{~Hz},[3 \mathrm{H}])$. Anal. required for $\mathrm{C}_{18} \mathrm{H}_{33} \mathrm{CeCl}_{6} \mathrm{~N}_{6}$ : C, 31.50; H, 4.85; N, 12.24\%. Found: C, 31.21; $\mathrm{H}, 4.58 ; \mathrm{N}, 12.54 \%$.

[EMIM $]_{3}\left[\mathbf{Y C l}_{6}\right]$. Synthesised in an analogous way, using $\mathrm{YCl}_{3}$ (100 mg, $0.512 \mathrm{mmol}$ ) and [EMIM]Cl (225 mg, $1.54 \mathrm{mmol})$. White crystalline product. Yield: $277 \mathrm{mg}, 85 \%$. Infrared (Nujol): 
Table 6 X-ray crystallographic data ${ }^{a}$

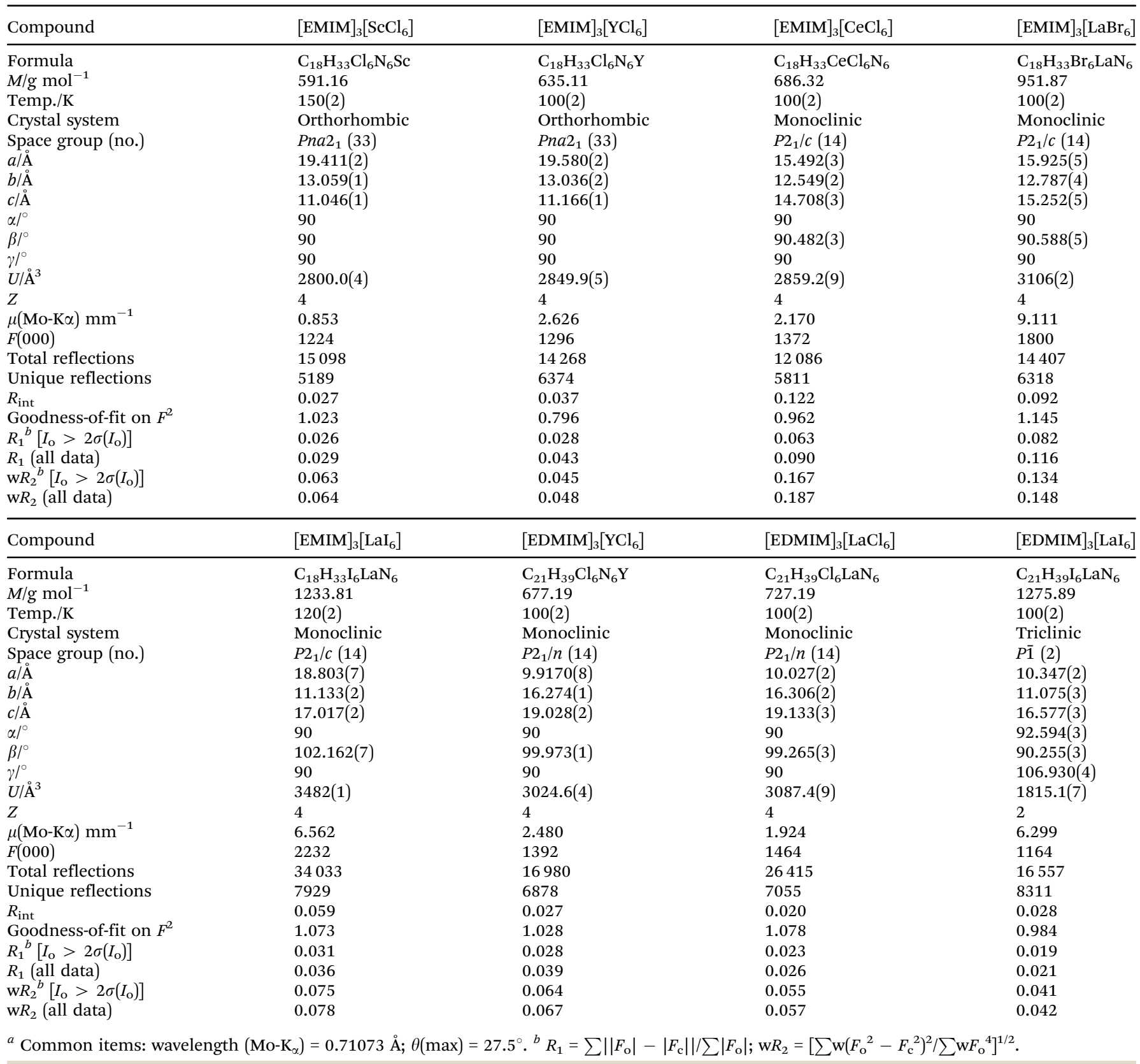

$245 \mathrm{~cm}^{-1}\left(\mathrm{~T}_{1 \mathrm{u}}\left[\mathrm{YCl}_{6}\right]^{3-}\right)$. Raman (solid): $264 \mathrm{~cm}^{-1}\left(\mathrm{~A}_{1 \mathrm{~g}}\left[\mathrm{YCl}_{6}\right]^{3-}\right)$. ${ }^{1} \mathrm{H}$ NMR $\left(\mathrm{CD}_{3} \mathrm{CN}, 300 \mathrm{~K}\right): \delta=9.26(\mathrm{~s},[\mathrm{H}]), 7.39(\mathrm{~s},[\mathrm{H}]), 7.34$ (s, [H]), 4.31 (q, $J=7.34 \mathrm{~Hz},[2 \mathrm{H}]), 3.93$ (s, [3H]), 1.46 (t, $J=$ $7.34 \mathrm{~Hz},[3 \mathrm{H}])$. Anal. required for $\mathrm{C}_{18} \mathrm{H}_{33} \mathrm{Cl}_{6} \mathrm{~N}_{6} \mathrm{Y}: \mathrm{C}, 34.04 ; \mathrm{H}$, 5.24; N, 13.23\%. Found: C, 33.90; H, 5.15; N, 13.18\%.

[EDMIM] $]_{3}\left[\mathbf{Y C l}_{6}\right]$. Synthesised in an analogous way, $72 \%$. White crystalline solid. Infrared (Nujol): $238 \mathrm{~cm}^{-1}\left(\mathrm{~T}_{1 \mathrm{u}}\left[\mathrm{YCl}_{6}\right]^{3-}\right)$. ${ }^{1} \mathrm{H}$ NMR $\left(\mathrm{CD}_{3} \mathrm{CN}, 300 \mathrm{~K}\right): \delta=7.40(\mathrm{~s},[2 \mathrm{H}]), 4.12(\mathrm{q}, J=7.16 \mathrm{~Hz}$, $[2 \mathrm{H}]), 3.75(\mathrm{~s},[3 \mathrm{H}]), 2.54(\mathrm{~s},[3 \mathrm{H}]), 1.39(\mathrm{t}, J=7.34 \mathrm{~Hz},[3 \mathrm{H}])$. $\left(\mathrm{CD}_{2} \mathrm{Cl}_{2}, 300 \mathrm{~K}\right): \delta=7.64(\mathrm{~d}, J=2.20 \mathrm{~Hz},[\mathrm{H}]), 7.46(\mathrm{~d}, J=2.20 \mathrm{~Hz}$, $[\mathrm{H}]), 4.23(\mathrm{q}, J=7.5 \mathrm{~Hz},[2 \mathrm{H}]), 3.97(\mathrm{~s},[3 \mathrm{H}]), 2.75(\mathrm{~s},[3 \mathrm{H}]), 1.50$ $(\mathrm{t}, J=7.34 \mathrm{~Hz},[3 \mathrm{H}]) \cdot{ }^{139} \mathrm{La} \mathrm{NMR}\left(\mathrm{CH}_{3} \mathrm{CN} / \mathrm{CD}_{3} \mathrm{CN}\right): \delta=864$ $\left(\mathrm{s}, W_{1 / 2}=600 \mathrm{~Hz}\right.$ ). Anal. required for $\mathrm{C}_{21} \mathrm{H}_{39} \mathrm{Cl}_{6} \mathrm{~N}_{6} \mathrm{Y}: \mathrm{C}, 37.25$; H, 5.80; N, 12.41\%. Found: C, 37.12; H, 5.93; N, $12.20 \%$.
$[\mathbf{E M I M}]_{3}\left[\mathbf{S c C l}_{6}\right]$. Synthesised in an analogous way, using $\mathrm{ScCl}_{3}$. White crystalline product, $85 \%$. Infrared (Nujol): $290 \mathrm{~cm}^{-1}$ $\left(\mathrm{T}_{1 \mathrm{u}}\left[\mathrm{ScCl}_{6}\right]^{3-}\right) .{ }^{1} \mathrm{H}$ NMR $\left(\mathrm{CD}_{3} \mathrm{CN}, 300 \mathrm{~K}\right): \delta=9.41(\mathrm{~s},[\mathrm{H}]), 7.41$ $(\mathrm{s},[\mathrm{H}]), 7.38,(\mathrm{~s},[\mathrm{H}]), 4.26(\mathrm{q}, J=7.34 \mathrm{~Hz},[2 \mathrm{H}]), 3.90(\mathrm{~s},[3 \mathrm{H}]), 1.46$ $(\mathrm{t}, J=7.21 \mathrm{~Hz},[3 \mathrm{H}]) .{ }^{45} \mathrm{Sc} \mathrm{NMR}\left(\mathrm{CH}_{3} \mathrm{CN} / \mathrm{CD}_{3} \mathrm{CN}\right): \delta=254.5$. Anal. required for $\mathrm{C}_{18} \mathrm{H}_{33} \mathrm{Cl}_{6} \mathrm{~N}_{6} \mathrm{Sc}$ : C, 36.57; $\mathrm{H}, 5.63 ; \mathrm{N}, 14.22 \%$. Found: $\mathrm{C}$, 36.39; $\mathrm{H}, 5.71 ; \mathrm{N}, 14.09 \%$.

X-ray experimental. Crystals suitable for single crystal X-ray analysis were obtained as described above. Details of the crystallographic data collection and refinement parameters are given in Table 6. Data collections were carried out on a Rigaku AFC12 goniometer equipped with an enhanced sensitivity (HG) Saturn724+ detector mounted at the window of an FRE+ SuperBright molybdenum rotating anode generator $\left(\lambda_{1}=0.71073 \AA\right)$ with 
VHF Varimax optics (70 or $100 \mu \mathrm{m}$ focus), apart from [EMIM] $]_{3}\left[\mathrm{LaI}_{6}\right]$ which was collected on a Rigaku R-axis Spider including curved Fuji-film image plate and a graphite monochromated sealed tube Mo generator $\left(\lambda_{1}=0.71073 \AA\right.$ ) . For all datasets: cell determination, data collection, data reduction, cell refinement and absorption correction were carried out using CrystalClear-SM Expert 2.0 r7. ${ }^{15}$

Structure solution and refinement were straightforward using WinGX and software packages within, ${ }^{16}$ except as detailed below. Although Q-peaks corresponding to the location of protons were observed in the Fourier difference map, hydrogen atoms were placed in geometrically assigned positions with $\mathrm{C}-\mathrm{H}$ distances of $0.95 \AA(\mathrm{CH}), 0.98 \AA\left(\mathrm{CH}_{3}\right)$ or $0.99 \AA\left(\mathrm{CH}_{2}\right)$ and refined using a riding model, with $U_{\text {iso }}(\mathrm{H})=1.2 U_{\text {eq }}(\mathrm{C})\left(\mathrm{CH}, \mathrm{CH}_{2}\right)$ or $1.5 U_{\text {eq }}(\mathrm{C})$ $\left(\mathrm{CH}_{3}\right)$. Mercury ${ }^{17}$ and enCIFer ${ }^{18}$ were used to prepare material for publication.

All the crystals of $[\mathrm{EMIM}]_{3}\left[\mathrm{CeCl}_{6}\right]$ looked at in this study were multiply twinned and all attempts at multi-component twin integration failed. A satisfactory dataset was obtained by integrating on just the major component and ignoring the minor overlaps from the other domains. This caused a couple of large Q-peaks to appear close to the cerium atoms $\left(3.2 \mathrm{e} \AA^{-3}\right.$ at $\sim 1.04 \AA$ distance from Ce) as well as two large holes $\left(-5.9{\mathrm{e} \AA^{-3}}^{-3}\right.$ at $\sim 0.84 \AA$ from Ce). This explains the level A and B CheckCIF errors PLAT971_ALERT_2_A (holes) and PLAT971_ALERT_2_B (Q-peaks). The crystals of $[\mathrm{EMIM}]_{3}\left[\mathrm{LaBr}_{6}\right]$ were all also multicomponent twins and treated in a similar fashion.

\section{Acknowledgements}

This work was funded by EPSRC through a Programme Grant (EP/I033394/1) and also through EP/K039466/1. The SCFED Project (www.scfed.net) is a multidisciplinary collaboration of British universities investigating the fundamental and applied aspects of supercritical fluids.

\section{References}

1 P. N. Bartlett, S. L. Benjamin, C. H. de Groot, A. L. Hector, R. Huang, A. Jolleys, G. P. Kissling, W. Levason, S. J. Pearce, G. Reid and Y. Wang, Mater. Horiz., 2015, 2, 420; P. N. Bartlett, D. A. Cook, C. H. de Groot, A. L. Hector, R. Huang, A. Jolleys, G. P. Kissling, W. Levason, S. J. Pearce and G. Reid, RSC Adv., 2013, 3, 15645.

2 J. Ke, W. Su, S. M. Howdle, M. W. George, D. Cook, M. PerdjonAbel, P. N. Bartlett, W. Zhang, F. Cheng, W. Levason, G. Reid,
J. Hyde, J. Wilson, D. C. Smith, K. Mallik and P. Sazio, Proc. Natl. Acad. Sci. U. S. A., 2009, 106, 14768; J. Ke, P. N. Bartlett, D. Cook, T. L. Easun, M. W. George, W. Levason, G. Reid, D. Smith, W. Su and W. Zhang, Phys. Chem. Chem. Phys., 2012, 14, 1517; P. N. Bartlett, J. Burt, D. A. Cook, C. Y. Cummings, M. W. George, A. L. Hector, M. M. Hasan, J. Ke, W. Levason, D. Pugh, G. Reid, P. W. Richardson, D. C. Smith, J. Spencer, N. Suleiman and W. Zhang, Chem. - Eur. J., 2016, 22, 302; C. Cummings, P. N. Bartlett, D. Pugh, G. Reid, W. Levason, M. M. Hasan, A. L. Hector, J. Spencer and D. C. Smith, J. Electrochem. Soc., 2014, 162, D619.

3 P. N. Bartlett, C. Y. Cummings, W. Levason, D. Pugh and G. Reid, Chem. - Eur. J., 2014, 20, 5019.

4 C. Y. Cummings, P. N. Bartlett, D. Pugh, G. Reid, W. Levason, M. M. Hasan, A. L. Hector, J. Spencer, D. C. Smith, S. Marks and R. Beanland, ChemElectroChem, 2016, 3, 679.

5 H. Ohno, Electrochemical Aspects of Ionic Liquids, Wiley, New York, 2005; Electrodeposition from Ionic Liquids, ed. F. Endres, A. P. Abbot and D. R. Macfarlane, Wiley, New York, 2008.

6 K. Matsumota, T. Tsuda, T. Nohira, R. Hagiwara, Y. Ito and O. Tamada, Acta Crystallogr., Sect. C: Cryst. Struct. Commun., 2002, 58, m186.

7 C. C. Hines, D. B. Cordes, S. T. Griffin, S. I. Watts, V. A. Cocalia and R. D. Rogers, New J. Chem., 2008, 32, 872. 8 A. Babai and A.-V. Mudring, Inorg. Chem., 2006, 45, 4874.

9 A. Babai and A.-V. Mudring, Inorg. Chem., 2005, 44, 8168.

10 K. Pohako-Esko, T. Wehner, P. S. Schulz, F. W. Heinemann, K. Muller-Buschbaum and P. Wasserscheid, Eur. J. Inorg. Chem., 2016, 1333.

11 J. Hallfeldt, PhD thesis, University of Hannover, 2003.

12 A. Babai and A.-V. Mudring, J. Alloys Compd., 2006, 418, 122.

13 (a) G. A. Jeffrey, An Introduction to Hydrogen Bonding, Oxford University Press, Oxford, 1997; (b) T. Steiner, Angew. Chem., Int. Ed., 2002, 41, 48.

14 R. D. Shannon, Acta Crystallogr., Sect. A: Cryst. Phys., Diffr., Theor. Gen. Crystallogr., 1976, 32, 751.

15 Rigaku Corporation, Tokyo, Japan, 2011.

16 L. J. Farrugia, J. Appl. Crystallogr., 2012, 45, 849.

17 C. F. Macrae, P. R. Edgington, P. McCabe, E. Pidcock, G. P. Shields, R. Taylor, M. Towler and J. van de Streek, J. Appl. Crystallogr., 2006, 39, 453.

18 F. H. Allen, O. Johnson, G. P. Shields, B. R. Smith and M. Towler, J. Appl. Crystallogr., 2004, 37, 335. 